Check for updates

Cite this: RSC Adv., 2020, 10, 25679

\title{
Degradation pathway and microbial mechanism of high-concentration thiocyanate in gold mine tailings wastewater
}

\author{
Lei Li, (D) a Fanyao Yue, ${ }^{b}$ Yancheng Li, ${ }^{\text {ac }}$ Aijiang Yang, ${ }^{\text {ac }}$ Jiang Li, ${ }^{\text {ac }}$ Yang Lv ${ }^{a}$ \\ and Xiong Zhong ${ }^{a}$
}

\begin{abstract}
As one of the inorganic pollutants with the highest concentration in the waste water of gold tailings using biohydrometallurgy, thiocyanate $\left(\mathrm{SCN}^{-}\right)$was effectively degraded in this research adopting a two-stage activated sludge biological treatment, and the corresponding degradation pathway and microbial community characteristics in this process were also studied. The results showed that $\mathrm{SCN}^{-}$at $1818.00 \mathrm{mg} \mathrm{L}^{-1}$ in the influent decreased to $0.68 \mathrm{mg} \mathrm{L}^{-1}$ after flowing through the two-stage activated sludge units. Raman spectroscopy was used to study the changes of relevant functional groups, finding that $\mathrm{SCN}^{-}$was degraded in the COS pathway. Based on 16S rRNA high-throughput sequencing technology, the microbial diversity in this system was analyzed, and the results indicated that Thiobacillus played a major role in degrading $\mathrm{SCN}^{-}$, of which the abundance in these two activated sludge units was $32.05 \%$ and $20.37 \%$, respectively. The results further revealed the biological removal mechanism of $\mathrm{SCN}^{-}$in gold mine tailings wastewater.
\end{abstract}

Received 14th April 2020

Accepted 26th June 2020

DOI: $10.1039 / \mathrm{dOra03330h}$

rsc.li/rsc-advances economic and environmental-friendly method, biohydrometallurgy is attracting more and more attention. Considering that $\mathrm{SCN}^{-}$consists of $\mathrm{S}, \mathrm{C}$ and $\mathrm{N}$, which are all necessary elements for the growth of the living beings, it can provide a carbon source, nitrogen source and sulfur source for microorganisms under aerobic conditions, and generate such metabolites as $\mathrm{SO}_{4}{ }^{2-}, \mathrm{CO}_{2}$, and $\mathrm{NH}_{4}{ }^{+} \cdot{ }^{9}$ Hence, high-load $\mathrm{SCN}^{-}$ in the wastewater can be biodegraded efficiently under the condition that dissolved oxygen and hydraulic retention time (HRT) are sufficient.

Biological treatment of $\mathrm{SCN}^{-}$can be generally divided into two parts: the carbon removal unit to decompose and release $\mathrm{CO}_{2}$, and the nitrification and denitrification unit to remove $\mathrm{NH}_{4}{ }^{+}-\mathrm{N}$ from wastewater. Now, bacteria including Arthrobacter, Escherichia, Methylobacterium, ${ }^{\mathbf{9}, \mathbf{1 0}}$ Bacillus, ${ }^{\mathbf{1 1}}$ Pseudomonas, Acinetobacter, ${ }^{\mathbf{1 2}}$ Thiobacillus, ${ }^{\mathbf{1 3}}$ Burkholderia, Chryseobacterium,${ }^{\mathbf{1 4}}$ Klebsiella and Ralstonia ${ }^{\mathbf{1 5}}$ and others, been isolated and identified from many resources to degrade thiocyanate. Paruchuri et al. found that the mixed culture containing Pseudomonas and Bacillus could degrade $\mathrm{SCN}^{-}$batch culture up to $1400 \mathrm{mg} \mathrm{L}^{-1}$ in 6 days. ${ }^{16}$ Chaudhari and Kodam isolated Klebsiella pneumoniae and Ralisto. sp co-cultures from thiocyanate-contaminated sites and found, ${ }^{15}$ the $\mathrm{SCN}^{-}$degradation rate was $500 \mathrm{mg}\left(\mathrm{L}^{-1} \mathrm{~d}^{-1}\right)$ at the concentration of $2500 \mathrm{mg} \mathrm{L}^{-1}$ thiocyanate at $\mathrm{pH} 6.0$ and $37{ }^{\circ} \mathrm{C}$. Different from physical and chemical treatment, biological treatment does not need a large number of oxidants and thus gradually becomes the research hotspot in respect of sulfur-containing cyanide wastewater treatment.
${ }^{a}$ College of Resources and Environmental Engineering, Guizhou University, Guiyang, Guizhou, 550025, China. E-mail: ycli3@gzu.edu.cn

${ }^{b}$ Guizhou Jinfeng Gold Mine Limited, Qianxinan Buyi and Miao Autonomous Prefecture, Qianxinan, Guizhou, 550025, China

${ }^{c}$ Guizhou Karst Environmental Ecosystems Observation and Research Station, Ministry of Education, Guiyang, Guizhou, 550025, China 
As a mature biological treatment process, activated sludge process plays an irreplaceable role in wastewater treatment. The large surface area and sugar layer of the activated sludge can quickly absorb pollutants in sewage, and effectively biodegrade pollutants relying on the relevant functional microorganisms. Hence, in this paper, a two-stage activated sludge biological treatment process is applied into the effective biodegradation of high-concentration thiocyanate $\left(\mathrm{SCN}^{-}\right)$in the gold mine tailings wastewater. Meanwhile, the functional groups in this system is analyzed to decode the degradation pathway of $\mathrm{SCN}^{-}$, and 16S rRNA high-throughput sequencing technology is also employed to analyze the microbial diversity in the system and further to explore the related biodegradation mechanism of $\mathrm{SCN}^{-}$.

\section{Materials and methods}

\subsection{Water quality and method of the test}

The tailing wastewater was selected from a gold mine in Guizhou Province, with the water quality shown as below: COD, $2089.00 \mathrm{mg} \mathrm{L}^{-1}$; $\mathrm{SCN}^{-}, 1818.00 \mathrm{mg} \mathrm{L}{ }^{-1} ; \mathrm{NH}_{4}{ }^{+}-\mathrm{N}, 1.98 \mathrm{mg} \mathrm{L}^{-1}$; $\mathrm{NO}_{2}{ }^{-}-\mathrm{N}, 4.30 \mathrm{mg} \mathrm{L}{ }^{-1}$; $\mathrm{NO}_{3}{ }^{-}-\mathrm{N}, 339.44 \mathrm{mg} \mathrm{L}{ }^{-1}$; and TOC, $707.76 \mathrm{mg} \mathrm{L}^{-1}$, in a mode of "regulating tank + two-stage activated sludge units + radial flow sedimentation tank". Influent flow reached $1000 \mathrm{~m}^{3} \mathrm{~d}^{-1}$ and the HRT of primary and secondary activated sludge units lasted $35.5 \mathrm{~h}$ and $10.5 \mathrm{~h}$, respectively, with the MLSS being $4000 \mathrm{mg} \mathrm{L}^{-1}$, and the dissolved oxygen $2.5-3.5 \mathrm{mg} \mathrm{L}^{-1}$. Then, the mixture is separated in the radial flow sedimentation tank, and the separated sludge flowed back to the primary unit, with the reflux ratio reaching $200 \%$. Sodium hydroxide solution was added to adjust $\mathrm{pH}$ value to 6-9 during operation. To ensure that a certain amount of organic matter can be provided for the growth and reproduction of microorganisms in the tanks, nutrition ratio of $\mathrm{C}: \mathrm{N}: \mathrm{P}$ should be maintained $100: 5: 1$. A nutrition dosing system for phosphorus solution was established to keep the balance of $\mathrm{C}, \mathrm{N}$ and $\mathrm{P}$ in the tanks. While the system became stable, wastewater quality in the regulating tank, the primary and the secondary activated sludge units was assayed, and the microorganism in these two units were also analyzed by 16S rRNA high-throughput sequencing.

\subsection{Sample collection and pretreatment}

Wastewater samples in the regulating tank was numbered (1), the primary activated sludge unit (2), and the secondary activated sludge unit (3). The sludge water mixture of the primary unit was marked $A$ and the sludge water mixture of the secondary unit was marked B. Sample (1) (2) (3) of 1 L was refrigerated in a cleaned and cold plastic bucket, and stored at $-4{ }^{\circ} \mathrm{C}$ in the laboratory, and Sample A and B of $1 \mathrm{~L}$ was collected and stored at $-20^{\circ} \mathrm{C}$ after centrifugation in the laboratory.

\subsection{Water quality index analysis}

The $\mathrm{pH}$ value was analyzed by $\mathrm{HACH}$ portable multi parameter digital analyzer, COD by rapid digestion spectrophotometry $(\mathrm{HJ} / \mathrm{T}$ 399-2007), $\mathrm{NO}_{3}{ }^{-}-\mathrm{N}$ and $\mathrm{NO}_{2}{ }^{-}{ }^{-\mathrm{N}}$ by ultraviolet spectrophotometry ( $\mathrm{HJ} / \mathrm{T} 346-2007), \mathrm{NH}_{4}{ }^{+}-\mathrm{N}$ by Nessler's reagent spectrophotometry (HJ 535-2009), TOC by NPOC (non purged organic carbon) in combustion oxidation non dispersive infrared absorption (HT 501-2009), $\mathrm{SCN}^{-}$by Isonicotinic acid pyrazolone spectrophotometry (GB/T13897-92), and total mercury by cold atomic absorption spectrophotometry (HJ 597-2011).

\subsection{Raman spectrum analysis}

The water samples were frozen at $-20{ }^{\circ} \mathrm{C}$ and then dried to powder. Then, a proper amount of powder was taken to the center of quartz slide for spectral integration using confocal micro Raman spectrometer (LRS-8, Shanghai, China), with excitation light source being $632.8 \mathrm{~nm}$ He-Ne laser, excitation wavelength $532.08 \mathrm{~nm}$, and grating $1800 \mathrm{~L} \mathrm{~mm}^{-1}$; and this process lasted $10 \mathrm{~s}$ and was repeated 4 times, in order to obtain a relatively smooth spectrum ranging form $100 \mathrm{~cm}^{-1}$ to $4000 \mathrm{~cm}^{-1}$. In addition, every spectrum sample was repeatedly collected three times to improve the accuracy. All the spectra were collected in a dark room at the laboratory temperature (23 ${ }^{\circ} \mathrm{C}$ ) and pressure (0.1 MPa). Original 8.0 software was used for data analysis.

\subsection{S rRNA high throughput sequencing analysis}

Microorganisms in the two units were collected and frozen at $-20{ }^{\circ} \mathrm{C}$, and then sent to Shanghai Meiji for 16S rRNA highthroughput sequencing. An universal bacterial primer: $338 \mathrm{~F}$ (5'-ACTCCTACGGGAGGCAGCAG-3'), was used to amplify V3V5. Microbial DNA was extracted for PCR amplification and product purification pre-experiment. Passing the preexperiment, the formal experiment could be initiated, using TransGen AP221-02: TransStart Fastpfu DNA Polymerase, $20 \mu \mathrm{L}$ reaction system: $5 \times$ FastPfu buffer $4 \mu \mathrm{L}, 2.5 \mathrm{mmol} \mathrm{L}^{-1} \mathrm{dNTPs} 2$ $\mu \mathrm{L}$, forward primer $(5 \mu \mathrm{M})$ and reverse primer $(5 \mu \mathrm{M}) 0.8 \mu \mathrm{L}$, FastPfu polymer $0.4 \mu \mathrm{L}$, BSA $0.2 \mu \mathrm{L}$, and template DNA $10 \mathrm{ng}$, then, adding ddH2O to $20 \mu \mathrm{L}$, as well as ABI GeneAmp ${ }^{\circledR} 9700$ PCR amplification instrument, with the reaction parameters: pre denaturation at $95{ }^{\circ} \mathrm{C}$ for $3 \mathrm{~min}$, denaturation temperature at $95{ }^{\circ} \mathrm{C}$ for $30 \mathrm{~s}$, annealing temperature at $55{ }^{\circ} \mathrm{C}$ for $30 \mathrm{~s}$, extension temperature at $72{ }^{\circ} \mathrm{C}$ for $45 \mathrm{~s}$, in 72 cycles, and extension at $72{ }^{\circ} \mathrm{C}$ for $10 \mathrm{~min}$. After amplification, PCR product sample of $3 \mathrm{~L}$ were loaded and assayed by $2 \%$ agarose gel electrophoresis. After that, an Illumina platform library was constructed, and then the data obtained were analyzed for biological information, including OTU clustering, species annotation and classification, community composition and others.

\section{Results and discussion}

\subsection{Degradation of $\mathrm{SCN}^{-}$by activated sludge process}

High-concentration $\mathrm{SCN}^{-}$wastewater was treated by two-stage activated sludge biological treatment process, in the stable period, water quality of the influent and effluent was shown in Table 1. Among them, $\mathrm{SCN}^{-}$decreased from $1818.00 \mathrm{mg} \mathrm{L}^{-1}$ to $1.01 \mathrm{mg} \mathrm{L}^{-1}$ and the removal rate reached $99.94 \%$ after the flowing through the primary unit, and then, the total removal 
Table 1 Water quality features of influent and effluent in the gold mine tailing wastewater

\begin{tabular}{|c|c|c|c|c|c|c|}
\hline Index & (1) & (2) & Removal efficiency 1 & (3) & Removal efficiency 2 & Total removal rate \\
\hline $\mathrm{pH}$ & 8.82 & 7.13 & - & 6.66 & - & - \\
\hline $\mathrm{NH}_{4}{ }^{+}-\mathrm{N}\left(\mathrm{mg} \mathrm{L}^{-1}\right)$ & 99.21 & 318 & $-220.53 \%$ & 292 & $8.18 \%$ & $-194.33 \%$ \\
\hline $\mathrm{NO}_{2}{ }^{-}-\mathrm{N}\left(\mathrm{mg} \mathrm{L}^{-1}\right)$ & 4.3 & 0.275 & $93.6 \%$ & 0.0174 & $93.67 \%$ & $99.60 \%$ \\
\hline $\mathrm{NO}_{3}{ }^{-}-\mathrm{N}\left(\mathrm{mg} \mathrm{L}^{-1}\right)$ & 339.44 & 14.28 & $95.79 \%$ & 43.83 & $-67.42 \%$ & $87.09 \%$ \\
\hline $\mathrm{COD}\left(\mathrm{mg} \mathrm{L}^{-1}\right)$ & 2089 & 250.20 & $88.02 \%$ & 294.67 & $-17.77 \%$ & $85.89 \%$ \\
\hline TOC $\left(\mathrm{mg} \mathrm{L}^{-1}\right)$ & 707.76 & 41.918 & $94.08 \%$ & 23.658 & $43.56 \%$ & $93.89 \%$ \\
\hline $\mathrm{SCN}^{-}\left(\mathrm{mg} \mathrm{L}^{-1}\right)$ & 1818 & 1.01 & $99.94 \%$ & 0.68 & $32.67 \%$ & $99.96 \%$ \\
\hline $\mathrm{Hg}\left(\mathrm{ng} \mathrm{mL}^{-1}\right)$ & 47.79 & 46.74 & $2.20 \%$ & 1.47 & $96.85 \%$ & $96.92 \%$ \\
\hline
\end{tabular}

rate of $\mathrm{SCN}^{-}$increased to $99.96 \%$ after the secondary unit, which was consistent with the removal rate of COD $(85.89 \%)$ and the reduction rate of TOC in water (93.89\%). As a main source of COD in gold wastewater, decreases of $\mathrm{SCN}^{-}$concentration can lead to COD decrease.

After the treatment in the primary unit, the removal rate of $\mathrm{NO}_{2}{ }^{-}-\mathrm{N}$ and $\mathrm{NO}_{3}{ }^{-}-\mathrm{N}$ in the wastewater reached $93.6 \%$ and $95.79 \%$, respectively and only $\mathrm{NH}_{4}{ }^{+}-\mathrm{N}$ exhibited an upward trend from $99.21 \mathrm{mg} \mathrm{L}^{-1}$ to $318 \mathrm{mg} \mathrm{L}^{-1}$, suggesting $\mathrm{NH}_{4}{ }^{+}-\mathrm{N}$ was an intermediate product from $\mathrm{SCN}^{-}$degradation which further led to the accumulation of $\mathrm{NH}_{4}{ }^{+}-\mathrm{N}$ due to a lack of electron acceptors in the system. Theoretically, $100 \mathrm{mg} \mathrm{SCN}^{-}$can release $24 \mathrm{mg} \mathrm{NH}_{4}{ }^{+}-\mathrm{N}$, about $10 \%$ of which can be transformed into biomass by microorganism as nitrogen source, and the rest enter into the water body in a form of $\mathrm{NH}_{4}{ }^{+}$, resulting in the increase of $\mathrm{NH}_{4}{ }^{+}-\mathrm{N}$ concentration in water. ${ }^{12}$ On the other hand, Huang et al. found that the nitrification of $\mathrm{NH}_{4}{ }^{+}-\mathrm{N}$ was inhibited due to the existence of $\mathrm{SCN}^{-} .^{14}$

Formula (1): $\mathrm{SCN}^{-}$conversion path.

$$
\mathrm{SCN}^{-}+\mathrm{H}_{2} \mathrm{O} \rightarrow \mathrm{S}_{2}^{-}+\mathrm{NH}_{4}^{+}+\mathrm{CO}_{2}
$$

Then, after flowing through the secondary unit, $\mathrm{NH}_{4}{ }^{+}-\mathrm{N}$ in the wastewater decreased by $26 \mathrm{mg} \mathrm{L}^{-1}$, but $\mathrm{NO}_{3}{ }^{-}-\mathrm{N}$ increased by $29.55 \mathrm{mg} \mathrm{L}^{-1}$, showing nitrification occurred in this secondary unit. Moreover, it was found that mercury in this unit reduced from $47.79 \mathrm{ng} \mathrm{mL} \mathrm{mL}^{-1}$ to $1.47 \mathrm{ng} \mathrm{mL}^{-1}$ with the removal efficiency high up to $96.92 \%$, suggesting this system had a favorable condition to remove mercury.

\subsection{Raman analysis of $\mathrm{SCN}^{-}$degradation pathway}

The results showed that there were two pathways to degrade $\mathrm{SCN}^{-}$. One was COS pathway. Under the action of thiocyanate hydrolase, the nitrogen carbon bond in $\mathrm{SCN}^{-}$hydrolyzed to $\mathrm{COS}$ and $\mathrm{NH}_{3}$, where the $\mathrm{C}-\mathrm{S}$ bond was broken into $\mathrm{CO}_{2}$ and $\mathrm{H}_{2} \mathrm{~S}$, and $\mathrm{H}_{2} \mathrm{~S}$ oxidized to $\mathrm{SO}_{4}{ }^{2-}$. The other was $\mathrm{CNO}$ pathway. The sulfur carbon bond in $\mathrm{SCN}^{-}$was broken and hydrolyzed to cyanate $\left(\mathrm{CNO}^{-}\right)$and $\mathrm{HS}^{-}$, where $\mathrm{CNO}^{-}$was hydrolyzed into $\mathrm{NH}_{3}$ and $\mathrm{CO}_{2}$ by cyanate hydrolysis enzyme, and $\mathrm{S}^{2-}$ was further oxidized to sulfide and $\mathrm{SO}_{4}{ }^{2-}$. ${ }^{9}$

The COS pathway: ${ }^{15}$

$$
\mathrm{N} \equiv \mathrm{C}-\mathrm{S}^{-}+2 \mathrm{H}_{2} \mathrm{O} \rightarrow \mathrm{O}=\mathrm{C}=\mathrm{S}+\mathrm{NH}_{3}+\mathrm{OH}^{-}
$$

$$
\mathrm{O}=\mathrm{C}=\mathrm{S}+\mathrm{H}_{2} \mathrm{O} \rightarrow \mathrm{H}_{2} \mathrm{~S}+\mathrm{CO}_{2}
$$

It can be seen from the analysis of three groups of data by comparing the Raman spectrogram (Fig. 1) and Raman spectrogram analysis (Table 2) of water quality, there were two vibrations in the absorption band of sulfur carbon $\mathrm{C}-\mathrm{S}$ located at $730-600 \mathrm{~cm}^{-1}$ in the regulating tank, specifically speaking, $634 \mathrm{~cm}^{-1}$ and $757 \mathrm{~cm}^{-1}$, respectively. In the primary unit, there was only one vibration at $636 \mathrm{~cm}^{-1}$, and in the secondary unit, there was only one vibration at $627 \mathrm{~cm}^{-1}$, with the vibration frequency less than that in the regulating tank and the primary unit. At the same time, the $\mathrm{C} \equiv \mathrm{N}$ stretching vibration frequency of $\mathrm{M}-\mathrm{S}-\mathrm{C} \equiv \mathrm{N}$, a metal thiocyanate salt located at 2160$2040 \mathrm{~cm}^{-1}$, also appears in the water of the regulating tank. ${ }^{20,21}$ Tian et al. reported that the S-and $\mathrm{N}$-combined thiocyanate showed C-N stretching vibration in the range of 2050$2165 \mathrm{~cm}^{-1}$, that is to say, this peak belongs to $\mathrm{C} \equiv \mathrm{N}$ stretching vibration, and the absorption band in the secondary activated sludge unit is the weakest, indicating that the $\mathrm{C}-\mathrm{S}$ bond and $\mathrm{C} \equiv \mathrm{N}$ bond fracture of $\mathrm{SCN}^{-}$(electronic formula is $\mathrm{N} \equiv \mathrm{C}-\mathrm{S}^{-}$) mainly occur in the primary activated sludge unit. The $\mathrm{C}=\mathrm{S}$ stretching vibration peak at $1200-1020 \mathrm{~cm}^{-1}$ only appeared in the regulating tank and the primary effluent, and disappeared in the secondary effluent, indicating that the $\mathrm{C}=\mathrm{S}$ bond fracture of $\mathrm{O}=\mathrm{C}=\mathrm{S}$ mainly occurred in the secondary unit. ${ }^{22}$ In Minogue's report, the Raman spectral frequencies of $981 \mathrm{~cm}^{-1}$ and $451 \mathrm{~cm}^{-1}$ belong to the vibration of $\mathrm{SO}_{4}{ }^{2-}$. The vibration

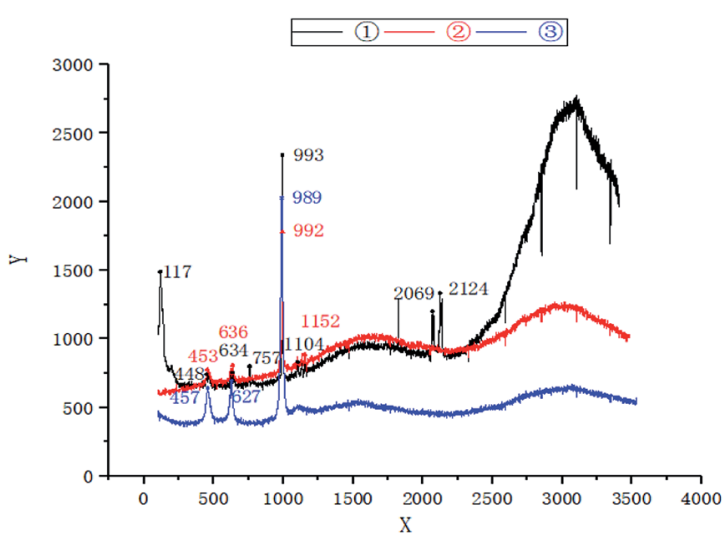

Fig. 1 Raman spectrum analysis of water quality-(1): regulating tank; (2): primary activated sludge unit; (3): secondary activated sludge unit. 
Table 2 Result of Raman spectroscopic analysis

\begin{tabular}{lll}
\hline Vibration mode & Vibration frequency & References \\
\hline The symmetric angle of $\mathrm{SO}_{4}{ }^{2-}$ & $460 \mathrm{~cm}^{-1}$ & 17 and 18 \\
Sulfur carbon C-S & $730-600 \mathrm{~cm}^{-1}$ & 19 \\
$\mathrm{SO}_{4}{ }^{2-}$ symmetric expansion & $1000-950 \mathrm{~cm}^{-1}\left(\right.$ about $\left.980 \mathrm{~cm}^{-1}\right)$ & 17 and 18 \\
$\mathrm{C}=\mathrm{S}$ expansion vibration & $1200-1020 \mathrm{~cm}^{-1}$ & 20 \\
$\mathrm{M}-\mathrm{S}-\mathrm{C} \equiv \mathrm{N}$ expansion & $2160-2040 \mathrm{~cm}^{-1}$ & 20 and 21
\end{tabular}

frequency (about $460 \mathrm{~cm}^{-1}$ ) caused by the symmetric angle change of $\mathrm{SO}_{4}{ }^{2-}$ from the regulating tank to the primary effluent changed slightly, but then weakened to the lowest extent in the secondary effluent; however, the $\mathrm{S}-\mathrm{O}$ symmetric stretching vibration peak (about $980 \mathrm{~cm}^{-1}$ ) of $\mathrm{SO}_{4}{ }^{2-}$ was very strong at the beginning, and then weakened gradually from the regulating tank to the primary effluent and then to the secondary effluent, indicating that $\mathrm{H}_{2} \mathrm{~S}$ can be further oxidized into $\mathrm{SO}_{4}{ }^{2-}$ both in the primary and secondary units. Accordingly, Raman spectrum analysis indicated that biodegradation of $\mathrm{SCN}^{-}$belonged to COS pathway, where the $\mathrm{N}-\mathrm{C}$ bond and $\mathrm{S}-\mathrm{C}$ bond in $\mathrm{SCN}^{-}$was hydrolyzed into $\mathrm{COS}$ and $\mathrm{NH}_{3}$ in the primary unit; then the C-S bond in $\mathrm{COS}$ was broken into $\mathrm{CO}_{2}$ and $\mathrm{H}_{2} \mathrm{~S}$ mainly in the secondary unit; and finally, $\mathrm{H}_{2} \mathrm{~S}$ was further oxidized into $\mathrm{SO}_{4}{ }^{2-}$.

\subsection{Analysis of microbial community structure}

Biofilms in the primary and secondary units were sampled for 16S rRNA high-throughput sequencing to analyze the bacteria community structure that degraded $\mathrm{SCN}^{-}$, and OTU clustering was carried out for non-repetitive sequences (excluding single sequences) according to $97 \%$ similarity by calculating common diversity indexes (Table 3) including richness index (Chao/ACE index), coverage index, Shannon index and Simpson index.

Couerage index refers to the sequencing depth and coverage rate of the samples. Coverage rates of sample A and B was 0.9996 and 0.9995 , respectively, indicating that most of the bacterial populations were detected. The small difference among Shannon index, Simpson index, ACE index and Chao index of sample A and B, as well as the Venn diagram of sample A and B microbial communities (Fig. 2) where the two sludge samples shared $90.63 \%$ of the total OTUs, proved similar microbial community diversity between them.

Further taxonomic analysis of OTU representative sequences found that over $95 \%$ of the microbial communities of A and B in the entire reaction were composed of three phylum-level bacterial communities (Fig. 3), referring to Proteobacteria, Bacteroidetes and Deinococcus Thermus, respectively, of which
Proteobacteria was the dominant with the respective abundance reaching $60.6 \%$ and $54.9 \%$. Bacteroidetes was the second dominant, accounting for $21.7 \%$ and $22.5 \%$, respectively. Manz et al. found that Proteobacteria possessed the capacity of water treatment. ${ }^{23}$ McLellan et al. also found that Bacteroidetes is the dominant bacteria in the influent of sewage treatment plant. ${ }^{24}$

The dominant family-level bacteria of the two samples were Hydrophillaceae, Chitinophagaceae and Trueperaceae, with the similar relative abundance (Fig. 4). Relative abundances of Hydrogenopholaceae in the sample A and B were $32.05 \%$ and $20.37 \%$, respectively. Thiobacillus, which has been reported to be capable of degrading $\mathrm{SCN}^{-}$, belongs to this family, and it is a special autotrophic bacterium which can utilize oxygen, nitrate and nitrite as electron acceptors to oxidize sulfide, thiosulfate and sulfur, so as to obtain energy. ${ }^{25,26}$ The respective relative abundance of Chitinophagaceae was $18.5 \%$ and $19.34 \%$, and Trueperaceae was $15.58 \%$ and $19.96 \%$. In addition, Burkholderiaceae, another one that can degrade $\mathrm{SCN}^{-}$, accounted for $2.65 \%$ and $2.9 \%$, respectively, in these two samples. As a degrading microorganism that can grow and metabolize with thiocyanate as the only carbon source. Burkholderia sp. can completely degrade $\mathrm{SCN}^{-}$of about $500 \mathrm{mg} \mathrm{L}^{-1}$ in $90 \mathrm{~h}^{{ }^{14}}$ It is reported that Burkholderiaceae can also degrade hydrocarbons, phenol and PAHs (pyrene) in coking wastewater. ${ }^{27,28}$

As shown in Fig. 5, the dominant genera-level bacteria of the two samples were Thiobacillus (32.05\% and $20.37 \%)$, Truepera (15.58\% and $19.96 \%)$, Chitinophagaceae (13.45\% and $14.02 \%)$, and Dokdonella (7.95\% and 10.94\%). Oxidation-reduction sulfide or elemental sulfur of Thiobacillus was sulfuric acid, and as a specific autotrophic bacterum using chemical energy, Thiobacillus could effectively degrade $\mathrm{SCN}^{-}$, during which $\mathrm{SCN}^{-}$ would generate metabolites such as $\mathrm{NH}_{3}, \mathrm{NO}_{2}{ }^{-}$and $\mathrm{S}_{2}{ }^{-}{ }^{29}$

The results showed that thiocyanate can be degraded in two pathways: Thiobacillus, a $\mathrm{SCN}^{-}$degrading bacterium isolated from coking wastewater treatment plant, belonged to COS degradation pathway, ${ }^{30}$ while Pseudomonas Putida and Pseudomonas stutzeri, separated from gold smelting wastewater

Table 3 Diversity indexes

\begin{tabular}{lllllr}
\hline Sample & Sequences & OTUs & Shannon & ACE richness & Chao richness \\
\hline A & 38146 & 154 & 2.65 & 163.38 & 159.22 \\
B & 35886 & 151 & 2.81 & 160.50 & 158.16
\end{tabular}



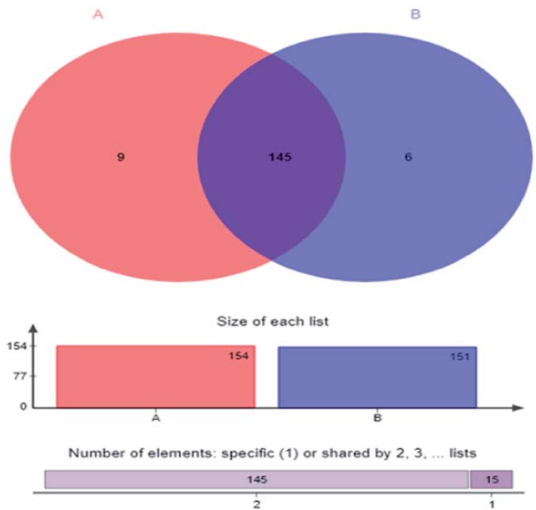

Fig. 2 Venn diagram of microbial community-A: primary activated sludge unit; B: secondary activated sludge unit.

polluted soil, belonged to CNO degradation pathway. ${ }^{31}$ Thiobacillus was the dominant strain in this experiment, suggesting the degradation of $\mathrm{SCN}^{-}$belonged to $\mathrm{COS}$ degradation pathway, ${ }^{30}$ consistent with the afore results of Raman spectrum analysis.

Moreover, results of this experiment can reaffirm some of other researches. For example, Kelly et al. put forward that COS can generate $\mathrm{CO}_{2}$ and $\mathrm{H}_{2} \mathrm{~S}$ through $\mathrm{C}-\mathrm{S}$ bond fracture, ${ }^{32}$ and $\mathrm{H}_{2} \mathrm{~S}$ can further oxidize to generate $\mathrm{SO}_{4}{ }^{2-}$, where the resulting energy can also facilitate the growth of microorganisms. Stratford et al. and Arakawa et al. extracted thiocyanate hydrolase from the isolated strain and identified that thiocyanate hydrolase was an inducible enzyme. ${ }^{33,34}$ Huddy et al. proved that Thiobacillus was the dominant bacteria to degrade $\mathrm{SCN}^{-}$in ASTER $^{\mathrm{TM}}$ biological treatment system using gene clone library analysis. ${ }^{35}$ In addition, the anammox bacteria Candidatus Campbell bacteria was detected, but its abundance was very small, about $0.17 \%$, so it exerted a poor effect on the removal of $\mathrm{NH}_{4}{ }^{+}-\mathrm{N}$.

The sequencing results showed that the nitrifying bacteria and nitrobacteria were not the dominant, and were excluded in the community Heatmap diagram (Fig. 5). What's more, results

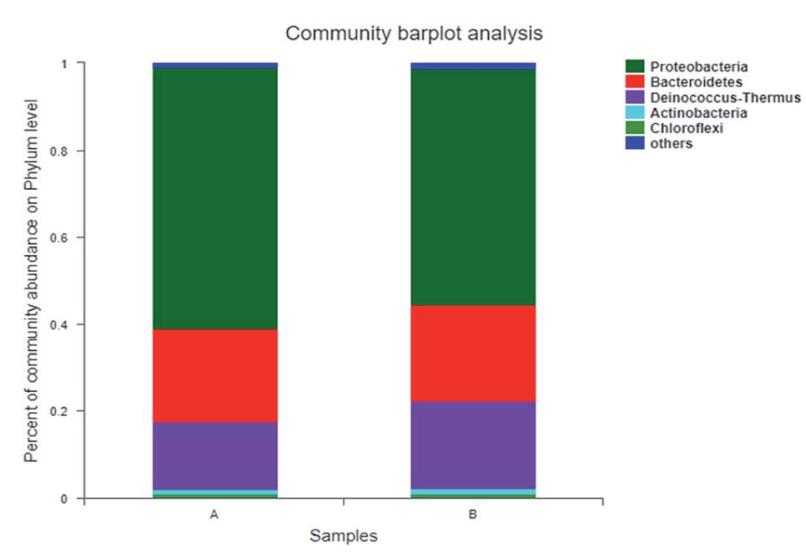

Fig. 3 Microbial classification at a Phylum level-A: primary activated sludge unit; B: secondary activated sludge unit.

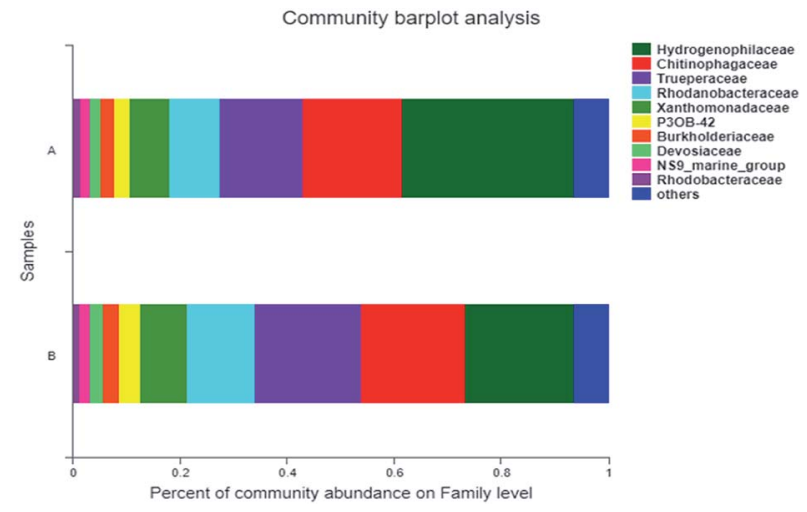

Fig. 4 Microbial classification at a Family level-A: primary activated sludge unit; B: secondary activated sludge unit.

in Table 1 also verified that the ammonia nitrogen in this system did not decline. The reason might be that Thiobacillus became the dominant bacteria, and oxidized sulfur to sulfate, causing the $\mathrm{pH}$ value of the system decreased. However, nitrifying bacteria prefer a relatively weak alkaline environment. Kim et al. also studied that nitrifying bacteria in aerobic sludge cannot be detected due to the inhibition of toxic compounds. ${ }^{36}$ Hence, nitrifying bacteria were not dominant in this experimental condition.
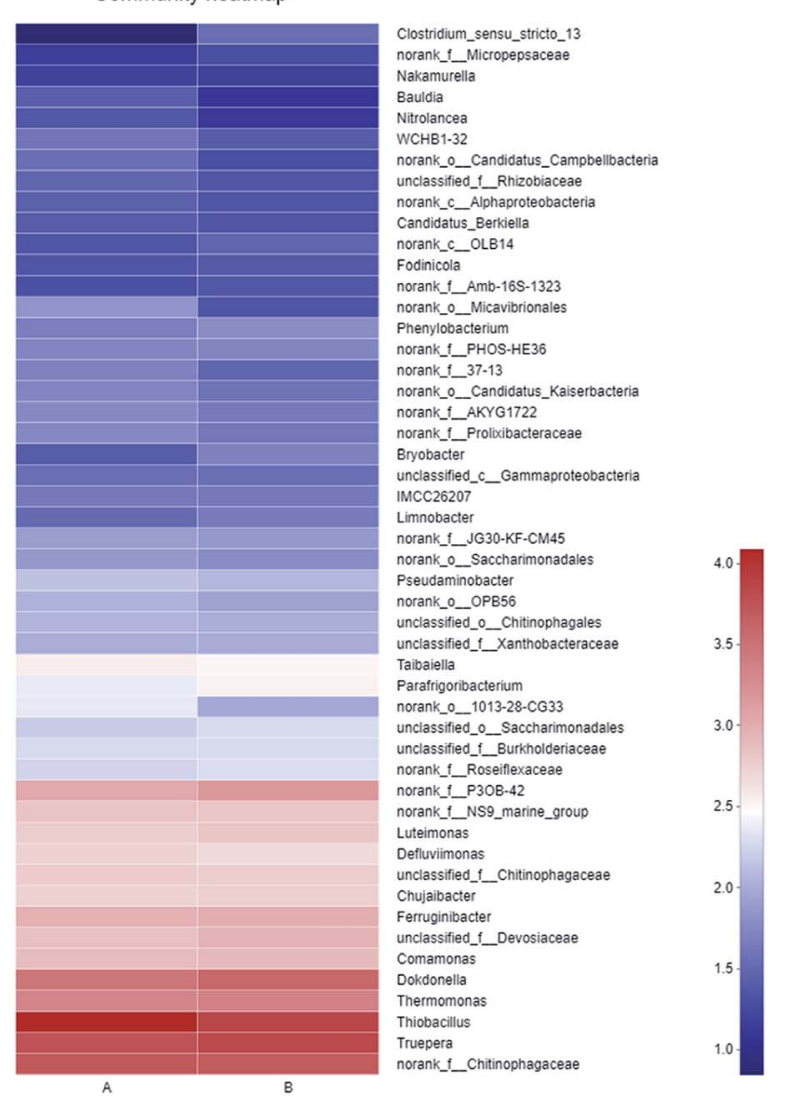

Fig. 5 Heatmap of microbial community (A: primary activated sludge unit; B: secondary activated sludge unit). 


\section{Conclusions}

In this research, high-concentration $\mathrm{SCN}^{-}$gold tailing wastewater was treated in a two-stage serial activated sludge process, where $\mathrm{SCN}^{-}$of $1818 \mathrm{mg} \mathrm{L}^{-1}$ was reduced to $0.68 \mathrm{mg} \mathrm{L}^{-1}$, with the degradation efficiency high up to $99.96 \%$. In addition, the removal efficiency of COD, TN and $\mathrm{Hg}$ reached 85.89\%, 85.51\% and $96.92 \%$, respectively. Meanwhile, according to Raman spectrum analysis of the functional groups' changes, $\mathrm{SCN}^{-}$was transformed and degraded in the same COS pathway as thiocyanate was biodegraded. Analysis of 16S rRNA highthroughput sequencing identified. Thiobacillus was the dominant bacteria to degrade $\mathrm{SCN}^{-}$, with the abundance of $32.05 \%$ and $20.37 \%$ respectively in the two-stage activated sludge units.

\section{Conflicts of interest}

The authors declare that there are no conflicts to declare.

\section{Acknowledgements}

This work was supported by Guizhou Science and Technology Plan Project ([2019]1079); Talent Base Project of Guizhou Province (Grant No. RCJD2018-21); and Talent Introduction Project of Guizhou Province (2017) No. 74.

\section{References}

1 S. L. Budaev, A. A. Batoeva and B. A. Tsybikova, Miner. Eng., 2015, 81, 88-95.

2 A. Akcil, Biotechnol. Adv., 2003, 21, 501-511.

3 N. Kuyucak and A. Akcil, Miner. Eng., 2013, 50-51, 13-29.

4 M. Kitis, E. Karakaya, N. O. Yigit, G. Civelekoglu and A. Akcil, Water Res., 2005, 39, 1652-1662.

5 I. R. Wilson and G. M. Harris, J. Am. Chem. Soc., 1960, 82, 4515-4517.

6 B. Agarwal, P. Thakur and C. Balomajumder, Chem. Eng. Commun., 2013, 200, 1278-1292.

7 K. Osathaphan, T. Boonpitak, T. Laopirojana and V. K. Sharma, Water, Air, Soil Pollut., 2008, 194, 179-183.

8 E. E. Chang, H. Hsing, P. Chiang, M. Chen and J. Shyng, J. Hazard. Mater., 2008, 156, 560-567.

9 S. Ebbs, Curr. Opin. Biotechnol., 2004, 15, 231-236.

10 J. H. Ahn, J. Kim, J. Lim and S. Hwang, Biotechnol. Prog., 2004, 20, 1069-1075.

11 L. Changsoo, K. Jaai, C. Jinsoo and H. Seokhwan, Biodegradation, 2003, 14, 183-188.

12 C. Boucabeille, A. Bories and P. Ollivier, Biotechnol. Lett., 1994, 16, 425-430.
13 D. P. Kelly and A. P. Wood, Int. J. Syst. Evol. Microbiol., 2000, 50, 547-550.

14 H. Huang, C. Feng, X. Pan, H. Wu, Y. Ren, C. Wu and C. Wei, J. Biomater. Nanobiotechnol., 2013, 04, 37-46.

15 A. U. Chaudhari and K. M. Kodam, Appl. Microbiol. Biotechnol., 2010, 85, 1167-1174.

16 Y. L. Paruchuri, N. Shivaraman and P. Kumaran, Environ. Pollut., 1990, 68, 15-28.

17 H. G. M. Edwards and V. Fawcett, J. Mol. Struct., 1994, 326, 131-143.

18 F. Wang, Y. H. Zhang, S. H. Li, L. Y. Wang and L. J. Zhao, Anal. Chem., 2005, 77, 7148-7155.

19 E. B. Szostak, K. Dru Bicki and E. Mikuli,J. Mol. Struct., 2010, 970, 139-146.

20 Z. Q. Tian, B. Ren and B. W. Mao, J. Phys. Chem., 1997, 101, 1338-1346.

21 M. R. Mucalo and Q. Li, J. Colloid Interface Sci., 2004, 269, 370-380.

22 N. Minogue, E. Riordan and J. R. Sodeau, J. Phys. Chem. A, 2003, 107, 4436-4444.

23 W. Manz, M. Wagner, R. Amann and K. Schleifer, Water Res., 1994, 28, 1715-1723.

24 S. L. McLellan, S. M. Huse, S. R. Mueller-Spitz, E. N. Andreishcheva and M. L. Sogin, Environ. Microbiol., 2010, 12, 378-392.

25 F. Di Capua, S. H. Ahoranta, S. Papirio, P. N. L. Lens and G. Esposito, Process Biochem., 2016, 51, 1576-1584.

26 W. Xing, J. Li, Y. Cong, W. Gao, Z. Jia and D. Li, Bioresour. Technol., 2017, 229, 134-142.

27 S. Zhu, H. Wu, C. Wei, L. Zhou and J. Xie, Appl. Microbiol. Biotechnol., 2016, 100, 2033.

28 N. S. Abbai and P. Balakrishna, Mol. Biotechnol., 2013, 54, 900-912.

29 B. G. K. W. Ryu, Bioresour. Technol., 2015, 191, 496-504.

30 O. Takahiro, N. Keiichi, S. Masahiko, N. Yoshiko, K. Hiromi, O. Akashi, N. Hiroshi, D. Naoshi, M. Yasuhiko and O. Masafumi, J. Am. Chem. Soc., 2013, 135, 3818-3825.

31 N. V. Grigor Eva, T. F. Kondrat Eva, E. N. Krasil Nikova and G. I. Karavaiko, Microbiology, 2006, 75, 266-273.

32 D. Kelly, G. Malin and A. Wood, Microbial Growth on C1 Compounds, 1993, pp. 47-63.

33 J. Stratford, A. E. Dias and C. J. Knowles, Microbiology, 1994, 140(10), 2657-2662.

34 T. Arakawa, Y. Kawano, S. Kataoka, Y. Katayama, N. Kamiya, M. Yohda and M. Odaka, J. Mol. Biol., 2007, 366, 1497-1509.

35 R. J. Huddy, A. W. van Zyl, R. P. van Hille and S. T. L. Harrison, Miner. Eng., 2015, 76, 65-71.

36 Y. M. Kim, H. Park, K. H. Cho and J. M. Park, Bioresour. Technol., 2013, 134, 180-189. 